Western University

Scholarship@Western

Aboriginal Policy Research Consortium International (APRCi)

2002

\title{
Institutional Representations of Aboriginal People
}

Chris Paci

Follow this and additional works at: https://ir.lib.uwo.ca/aprci

Part of the Social and Cultural Anthropology Commons

Citation of this paper:

Paci, Chris, "Institutional Representations of Aboriginal People" (2002). Aboriginal Policy Research Consortium International (APRCi). 278.

https://ir.lib.uwo.ca/aprci/278 
This article was downloaded by: [University of Western Ontario]

On: 09 December 2012, At: 07: 19

Publisher: Routledge

Informa Ltd Registered in England and Wales Registered Number: 1072954 Registered office: Mortimer House, 37-41 Mortimer Street, London W1T 3J H, UK

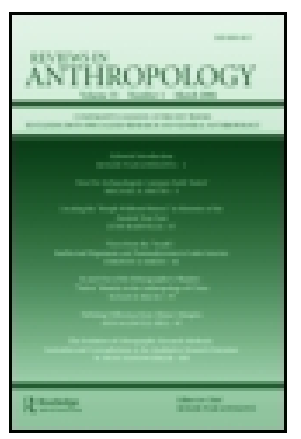

\section{Reviews in Anthropology}

Publication details, including instructions for authors and subscription information:

http:// www. tandfonline.com/loi/ grva20

\section{Institutional Representations of Aboriginal People}

Chris Paci

Version of record first published: 29 Oct 2010.

To cite this article: Chris Paci (2002): Institutional Representations of Aboriginal People, Reviews in Anthropology, 31:2, 165-183

To link to this article: http:// dx.doi.org/ 10.1080/00988150212936

\section{PLEASE SCROLL DOWN FOR ARTICLE}

Full terms and conditions of use: http://www.tandfonline.com/page/terms-and-conditions

This article may be used for research, teaching, and private study purposes. Any substantial or systematic reproduction, redistribution, reselling, loan, sub-licensing, systematic supply, or distribution in any form to anyone is expressly forbidden.

The publisher does not give any warranty express or implied or make any representation that the contents will be complete or accurate or up to date. The accuracy of any instructions, formulae, and drug doses should be independently verified with primary sources. The publisher shall not be liable for any loss, actions, claims, proceedings, demand, or costs or damages whatsoever or howsoever caused arising directly or indirectly in connection with or arising out of the use of this material. 
Reviews in Anthropology, Vol. 31, pp. 165-183

Copyright (c) 2002 Taylor \& Francis

$0093-8157 / 02 \$ 12.00+.00$

\title{
Institutional Representations of Aboriginal People
}

\author{
Chris Paci
}

Harless, Susan E., ed. Native Arts of the Columbia Plateau: The Doris Swayze Bounds Collection. Seattle: The University of Washington Press, 1998. xvi +136 pp. including chapter references and index. $\$ 50.00$ cloth.

Lewis, G. Malcolm, ed. Cartographic Encounters: Perspectives on Native American Mapmaking and Map Use. Chicago: The University of Chicago Press, 1998. $x x+318$ pp. Including chapter references and index. $\$ 60.00$ cloth.

Phillips, Ruth B. Trading Identities: The Souvenir in Native North American Art from the Northeast, 1700-1900. Seattle: The University of Washington Press, 1998. xvii +334 pp. including chapter references and index. $\$ 40.00$ paper.

Smithsonian Institution. The Changing Presentation of the American Indian: Museums and Native Cultures. Seattle: The University of Washington Press, 2000. 118 pp. including chapter references and index. $\$ 25.00$ cloth.

Representations of Aboriginal peoples, including the deeper structures of their aesthetics and philosophies, have been bounded by epistemologies,

CHRIS PACI PHD (Manitoba), MA (Carleton), BA (Winnipeg), is the Manager of Environment and Lands with the Dene Nation in Yellowknife, Northwest Territories, Canada. Chris has also been an Instructor of First Nations Studies, University of Northern British Columbia. He is a self-proclaimed product of decolonization, with roots in Manitoba. His research interests include decolonization, the Metis, traditional environmental knowledge, Aboriginal community resource planning, environmental history, interdisciplinarity and area studies, Action research, and decolonizing curriculum. Recent publications include a book chapter in Native Pathways, articles in the International Journal of Environmental Assessment and American Indian Culture and Research Journal, as well as book reviews in Anthropologica, Native Studies Review, Ethnohistory, and Canadian Journal of Natives Studies.

Address correspondence to Chris Paci, Manager, Environment and Lands, Dene National, Yellowknife, NT X1A $2 P 7$. 
metonymic tropes, institutions, and curio cabinets. Institutional representations exist in a number of forms. A great deal of collecting and display has been influenced by a desire to preserve traditions and material culture. However, the desire to preserve-conserve can be, at the same time, simultaneously alienating to traditions and material culture. The issue of representation is about more than developing a cultural sensitivity that acknowledges and celebrates differences, although such a paradigm shift would be indeed welcome. Problematizing Aboriginal representations strikes at the very roots of how traditions exist, cultures maintain and adapt, and to what use material culture ought to be applied. The discourse of Aboriginal representations is messy and patchy. Good intentions of many objective nonNative collectors, curators, and cultural experts have undermined the validity of Aboriginal cultures, most typically by adhering to ethnographic allegories of primitive precontact origins and cultural evolutionism. Institutions have presented oscillating images of Aboriginal peoples, from natural ecologist and noble savage to a host of other prefigurative master tropes (see David W. Penney [Smithsonian Institution 2000] in this review). Representations that demonstrated developmental change, reflexive of the sometimes uneasy settlement with Europeans, such as forged-forced partnerships during the fur trade era, were undervalued as inauthentic. Many institutions have chosen, based on very little expert knowledge, classical romanticism and aesthetics such as the sublime or picturesque, which marginalize Aboriginal peoples as fading tribes. Such presentations have been resisted and are challenged as false legitimacies created through the production of master narratives. Resistance refers to the subversion of such representations to counter the effects of certain master methods of collection and analysis. The knowledge gained by privileging written over oral, and separating cultural artifact from cultural process, somehow divorced from one's own culture, is subverted.

Since the early 1990s, public institutions across North America have struggled to find ways to improve their presentation of Aboriginal peoples. Canada's Minister of Heritage, Sheila Copps, announced funding of 1.23 million dollars for Aboriginal Museum development at a recent Parks Canada Round Table on Aboriginal Tourism (Canada News Wire 2001:1). The monies are meant to support twenty-two projects on Aboriginal culture as a component of the Museums Assistance Program. These dollars reflect a limited investment by the federal government to improve the way in which Aboriginal peoples are represented in public institutions. In an attempt to better engage and reflect perspectives and representations by Aboriginal participants the exact restructuring of these institutions is hotly debated. If parallels can be drawn between a number of different institutions, which have until recently been the exclusive domain of experts on Indians and all 
things Indian, then there is something at work akin to a paradigm or "museological shift," which is the term West uses in The Changing Presentation of the American Indian: Museums and Native Cultures (p. 99). Scholars in all disciplines, including newer area studies and hybrid disciplines, are producing manuscripts and theory that are relevant to questions regarding Aboriginal representations. In fact, many of these are being written by Aboriginal peoples in order to reflect their diverse perspectives.

Aboriginal peoples of Turtle Island have always represented themselves in a number of different ways, for a number of different audiences and for a number of different reasons. While trade in material culture existed between and among different linguistically and culturally unique Aboriginal groups, the vast majority of representations were consumed within a specific and local community; artifacts were part of cultural processes that may have included economics but were symbolic of much broader motivations. After contact in North America, diverse Aboriginal cultures became the objectified medium for various outsiders who reinscribed and translated Natives into European and other contexts. Natives became savages because it suited the colonizer, justifying barbaric acts and theft of land. Non-native representations served a variety of other purposes related to colonial consumption. Aboriginal people catered to the tastes of the tourist and other newcomers, packaging their material culture and representations for takeout customers. The construction and consumption of Aboriginal representations at home, at firesides in Europe, or elsewhere, are the beginnings of the development of cultural archives.

Under the gaze of interdisciplinary scholarship an examination of representations raises many issues. In much of the recent work discussed in this essay, a tension exists between Aboriginal and non-Native discussants regarding who should research and discuss Aboriginal representations. Whether discussing maps, souvenir, or textiles (clothing and decorative arts), representations are infused with meanings that take on a life all their own. Whose expertise is used to interrogate the medium for meanings and misunderstandings? Who views the cultural contacts, the events, and the subsequent telling of Aboriginal representations? In particular, the institutions perpetrating representations hold a great deal of sway over the message. Can we resist the temptations of master analysis and classification, with its familiarity and promise of attracting an audience? We try to order what is known about the world around us, about what other know and what others have said about specific temporal and spatial subjects, yet the freedom to generate authoritative representations is an issue of power with a long history of privileging few at the expense of others. Perhaps as a result of the failure of legitimizing forces to control research and access knowledge, or as a result of a desire to critique and produce better knowledge, counter 
hegemonic discourses are leaving the margins for the mainstream. The historically exclusive domain of select academics, scholars, collectors, illustrators, writers, and audience members is now open to a larger, albeit still far too narrow, group.

These are exciting times in which we live; there is no single definite truth to guide us out of a dreamt up cave of ignorance. In fact, we are finding that the imported allegories and metaphors of the past have been employed to emancipate some and enslave others; this dual nature is implicit in western cultural production, including the production of knowledge. There is nothing shocking to turn towards the land and stories of ancestors in order to understand our place as humans as part of nature, but we must also question to what degree appropriation is at work. The time has come for an evaluation of the reality of knowledge via an interdisciplinary reexamination of imported disciplinary products-schools, theories, languages, ideas, books, fieldwork, topics-into our present state. It is essential to find ways to engage Aboriginal communities and leadership in the redefinition of the cultural status quo when it comes to collecting and representing the practices of a host of cultural institutions. As a site of resistance, the transcultural is increasingly a space to interrogate hegemonic globalizing tendencies of the authentic and legitimate, which are used to displace and freeze tradition. The fact that much of the diversity of American and Canadian cultures is marginalized by unidimensional or silencing representations of institutions has been persistent, and a recently acknowledged characteristic.

There are glaring inaccuracies in much of what we see in the world around us. The questioning of representations is no longer the exclusive dominion of knowledge-hoarding experts. In the democratization of knowledge we have opened dependency on theory, facts, laws of nature to a much larger arena of debate. Much discussion is played out between the covers of books. In light of this interest, as well as the supply and demand for Aboriginal representations that still exists, the following ideas need to be addressed. Who has the authority to construct representations of Aboriginal peoples? Do those who are being represented have a say in how they are shown across time? Who is consuming representations, why, and what are the costs and benefits? Are we willing to accept false or more accurate depictions? Aboriginal cultures are equally susceptible to a number of influences, including exploitation, misrepresentation, and commercialization. In fact there is a long history of colonization of Aboriginal peoples and appropriation of their cultures through trade, tourism, and newcomers' fascination with these cultures. The hybrid result of many different exchanges has led to the challenging of rigid definitions for "Native-non-Native," and advocating the adoption of these new definitions. The appeal for fluidity is 
counter to the conservative "think" of many museums and art galleries, both private or public collections, that have born static images when it comes to the ways in which cultures are presented. Studying collectors and their collections must uncover something about the intimate forces at play in public institutions, such as personal taste, family histories, travels, and aesthetics.

One issue that continues to attract a considerable depth of scrutiny is the basis on which legitimacy to represent Aboriginal people will be consolidated (Said 1993). Critiques have placed the responsibility for misrepresentation squarely on the shoulders of esteemed institutions. For example, universities have been guided under the tutelage of college presidents and deans in the production of knowledge that has actually marginalized Aboriginal cultures. Research centers have been staffed by professionals and university graduates instead of community members; their work has been a reflection of their own perspectives, not those of Aboriginal communities. Museum galleries have grown out of different motivations, from collecting and displaying natural phenomenon to ethnography. Yet, in the hands of directors and curators these diverse interests have produced narrow windows through which to see the world, erasing much about Aboriginal culture that doesn't fit into their preconceived boxes. Likewise, archives controlled by keepers, archivists, and libraries, under the leadership of librarians and fueled by the acquisition of books (rare and otherwise), constrain the direction of scholarship. Even parks can not escape imperfect representations of Aboriginal peoples. Audiences, in all forms, have placed great demands on institutions to produce images that are both familiar and exotic, and these audiences reject changes to their entrenched ways of seeing and experiencing the world.

Primitivism and modernism, sometimes viewed as distinct periods, are intertwined intellectual projects. In other words, the same process of setting up "immutable mobiles," to borrow Latour's (1986) term, are used to insert a characteristic way of thinking about cultures. The periods are inseparable because they rely on both the production and consumption of idiosyncratic representations. The manufacturers of these representations are artists and artisans, researchers and scholars, cultural insiders produced a wide spectrum of material objects, from the mundane to the sacred. The objects are produced for the self and the market, and they are consumed and collected within an observable institutional mainstream. At the time of collecting representations, individuals and institutions have chosen to keep and study some objects instead of others. The ways in which collections are shown is a reflection of the ways in which "we" continue to structure cultural phenomena. During a senior undergraduate seminar on Inuit Art at the Winnipeg Art Gallery (WAG) some years ago, I found myself face-to-face with this 
paradigm. Offering a course at a public institution is of great value because it has the potential to expose students to instructors whose legitimacy is instrumental and supported by an organized institutional collection. I was amazed by the WAG's ability to amass an extensive number of sculptures, prints, and other material work by Inuit artists; this is especially impressive when considering the distance of Winnipeg from the Arctic. It became apparent that over the last fifty years there have been significant changes in how the Inuit and their art were shown to the world in permanent collections and traveling exhibitions. Examining the artifacts led me to question whether there was any documentation from the Inuit artists to help me understand the work, but in my studies I came across only cultural archives, which gave me some insight to the art and not the artists. The Inuit, like all people, had produced representations of themselves, through their aesthetics, and had traded their material culture with others for hundreds of years before the advent of what became the Inuit art industry.

Representations are more or less unique to spatial and temporal influences. Ruth Philips (1998), in her book Trading Identities: The Souvenir in Native North American Art from the Northeast, 1700-1900, examines souvenirs as discreet local traditions that are produced through hybrid commercialism. According to Philips, four types of collectors, including tourists, professional ethnographers, rare art collectors, and Native agents consume souvenirs as visual cognates. While souvenirs were collected en masse, maps are a more unique representation collected by explorers, missionaries, and traders. The maps described by the contributors to Cartographic Encounters: Perspectives on Native American Mapmaking and Map Use, are indicative of the contact zone where explorers and inhabitants sought to exchange representations of landscapes from vastly different worldviews. The transcultural nature of these contact representations indicates a suite of forces that can be, even with a balance of oral and extensive documentary support, poorly understood. The essays in Native Arts Of the Columbia Plateau: The Doris Swayze Bounds Collection (1998) demonstrate the limit of documentations and interpretation; no single theory can be used to comprehend all the forces that influence individuals and collectivities to act, produce, consume, collect, and display. Each time we ask and answer a question, we bring a personal and professional bias to the inquiry. In the anthology The Changing Presentation of the American Indian: Museums and Native Cultures (2000), essayists discuss how narratives have been enlisted to support or refute arguments about Aboriginal people (specific and general). The lesson from these books is that with good research we tell a good story.

In this review essay I examine a set of common research interests in these four books, representing a diverse group of scholars who study the institutional representations of Native people. These are four excellent books; 
each examines a part of the institutional representations of Aboriginal peoples in its own unique way. The books share in common the analysis of Aboriginal representations, most of which were consumed by non-Natives. Ruth Philips examines the souvenirs produced by Natives of the northeast. Philips' book, well illustrated and thoroughly researched, will be relevant, particularly because of her methodological approach, to students and teachers in art history, anthropology, history, and native studies. G. Malcom Lewis edited an anthology that examines Native maps, mapmaking, and use; and that is an engaging book that is relevant to archival studies, cartographygeography, history, and native studies. Similarly, Susan Harless edited an anthology on the Doris Swazye Bounds collection, which includes chapters by a number of essayists that speaks to select aspects of the collection. This book will be of interest to students of art history, anthropology, curatorial studies, and native studies. While Lewis examines Native maps from a number of different institutions, people, and geographies, Harless is concerned with a specific cultural- and geographic-based collection, and Philips examines a motif/form for a generalized cultural area. By juxtaposing these three books, the issues resulting from institutional representations are clarified. The anthology from the Smithsonian Institution is an interesting collection of seven essays, based on conference proceedings, that describe the presentation of Aboriginal cultures in museums. This anthology is arguably a most powerful lens through which to understand the state of discourse on Aboriginal re-presentations today.

Susan E. Harless (1998), editor of Native Arts of the Columbia Plateau, has gathered an impressive collection of seven essays that are well illustrated with large color and black-and-white photos. The book combines two genres, that of biography and art gallery exhibition catalogue. The discussions of the life of Doris Swayze Bounds, her collection practices, and the artifacts and artworks that represent aesthetics and traditions of Native artisans of the Columbia Plateau sit comfortably side by side. While Bounds is an impressive historical figure in her own right, as a graduate student at Columbia University she was most probably exposed to the collection and practices of Doris and George Heye; the book is an uncritical tribute. In a more hostile environment, researchers might be more critical of the collection and Bounds' practices, as individual pieces shift from collateral or result from salvage bargain shopping. Furthermore, some of the pieces were first shown as decoration on the walls of the Inland Empire Bank in Umatilla. While it is argued that public display of Aboriginal curios provided a high profile for Aboriginal cultures, such practices of power are tainted by desire for postinvasion acculturation. The negative effects of the public display of "booty" can be easily imagined; however, none of the essayists in the collection make such observations. In fact, Bounds is fixed in her role as 


\section{C.Paci}

interlocuter, banker, businesswoman, and collector of Native American Art. While much is written and could be said about the life of Bounds in her role as collector and appreciator of Native Art, the book provides into the present collection at the High Desert Museum in Bend, and to a lesser extent the evolution of the Arts in Oregon. The "Bounds Collection" amassed since the 1920s, contains material that spans a period from 1870 to the 1960s. Many of the items in the collection are basketry, exquisitely beaded handbags, dresses, and other textile items. To say that the collection represents a gendered view of the Columbia Plateau peoples would not be inaccurate. This book is a thought-provoking counterpoint to male-dominant exhibitions that dwelt on constructing collections of lithics, tools, and hunting implements.

A combination of Aboriginal and non-Native writers, whose knowledge of their subject is both intimate and revealing, is a high point in the anthology edited by Harless. Katherine S. French introduces the book by contextualizing Doris Swayze Bounds and the beautiful works she acquired. During her lifetime, Bounds collected items from the Columbia River Plateau, an area that " tended to suffer by comparison with other regions. The complexity and vividness of the cultures of the southwest, the Northwest Coast, and the Great Plains, and a lack of adequate information, led to the Plateau's being represented as a pale reflection of surrounding areas, characterized mostly by what was absent" ( $p$. xiii). The collection is a break in the Plateau Indians' traditional sharing and distribution of material goods. French notes, "goods were acquired to be given away... Doris Bounds became a part of this network of reciprocity because of her friendships and her contributions to these people's lives" (p. xv). While her "Indian friends" practiced their traditions, so too did Bounds practice hers. In the typical non-Native practice, Bounds hoarded and collected exotic Indian artifacts by removing materials from intended cultural contexts.

There are significant essays on Bounds' collecting methods and life in Harless' book. For example, the essays "Doris Swayze Bounds: Collector of objects, collector of friends" by Harless (pp. 3-28) and Vivian M. Adams's, "In a spiritual way: A portrait of Plateau spirituality in traditional art" (pp. 29-39). The bulk of the essays in the book examine aesthetic traditions revealed by the collection and its changing conditions, including the movement from private to public. Such pivotal essays include "The Plateau culture area and its arts: Toward understanding of Plateau aesthetics" by Richard G. Conn (pp. 40-56); Mary Dodds Schlick's, "Handsome things: Basketry arts of the Plateau" (pp. 57-70); "Transmontane beading: A statement of respect" by Barbara Loeb and Marnard White Owl Lavadour (pp. 71-86); and Kate C. Duncan's, "Honoring people, honoring life: Floral and figural beadwork on the Plateau (pp. 87-102). "Doris Bounds' role in contemporary native pageantry," by Barbara A. Hail with comments by Lillian 'Sis' 
Moses (pp. 103-107), reveals the involvement of the collector. Unfortunately, it tells us little of Doris Swayze Bounds's motives or the implications her involvement had in the lives of "Plateau" people. The "Afterword" by Vivian Adams is a very effective and insightful discussion of museumology and the history of museum collections. Adams cautions that the context for Aboriginal representations have been "frenzied and competitive collection efforts [that] produced the collections now found throughout the United States and worldwide in museums and in private ownership" (p. 108).

In 1995, the National Museum of the American Indian (NMAI), Smithsonian Institution, hosted a symposium, "The changing presentation of the American Indian," which attracted both American and Canadian scholars to the George Gustav Heye Center in New York. The NMAI was established in 1989 from the consolidation of a substantial and vast collection of American Indian artifacts and representations. The Changing Presentation of the American Indian: Museums and Native Cultures, is a documentary record of the 1995 symposium, which consists of seven essays (nine if you count the appendices, articles from W. Richard West and Richard W. Hill, Sr.) from both Aboriginal and non-Aboriginal museum authorities. The anthology is rich with both the theoretical and practical experience of seasoned curators, professors, and museum directors. The essays are predictably concise, but on the whole they provoke a reconsideration of the way in which institutions present Aboriginal cultures.

W. Richard West, Director of the NMAI, writes in "A new idea of ourselves: The changing presentation of the American Indian," that "authentic voice and perspective guide polic[ies]" and traditional aboriginal cultures are dynamic, not static (p. 7). West notes a "need for museums to involve Native communities in exhibition preparations, and for the creation of new technologies best suited to presenting Native American culture" (p. 12) In "Presenting the American Indian: From Europe to America" (pp. 15-28), Evan M. Mauer, the Director of the Minneapolis Institute of the Arts, traces the roots of representations to publications in 1505 through encounters such as the English-Inuit on Baffin Island. The "Scientific cabinet" is problematized along with a desire for "reacculturation" of Aboriginal representations, perhaps made more poignant by recent legal debate raised by the reinterpretation and application of the Native American Graves Protection and Repatriation Act to the Kennewick man. Many of the points raised by West are further elaborated on by James D. Nason, Director of the American Indian Studies Center at the University of Washington, in "'Our' Indians: The unidimensional Indian in the disembodied local past" (pp. 29-46). Nason examines the "curator in control" idea along with aesthetics from the sublime to the ridiculous (p. 32). Through examining the history of the American history museum, Nason identifies several types of exhibitions and dis- 


\section{C.Paci}

plays: geographical or ethnographical exhibition; developmental exhibition; life group display; and display/open storage. Regrettably, collections based on the dying savage trope continue to influence exhibition. "The poetics of museum representations: Tropes of recent American Indian art exhibitions" (pp. 47-66), by David W. Penny, curator at the Detroit Institute of Arts, is a thorough examination of the underlying narratives that are essential to the creation and viewing of museum exhibitions. According to Penny, many of the most significant exhibitions are indicative of the changing metonymic tropes associated with culture areas and tribes, which are part of the larger epistemology of prefigurative master tropes employed by museum exhibitions for public consumption. Penny argues that ideology underlies exhibition rhetoric; even those changes seeking; to better represent Aboriginal peoples or contextualize their artifacts within a larger set of understandings will ultimately lead to confusion and resistance on the part of different segments of the public.

Janice Clements, in "The integration of traditional Indian beliefs into the museum at Warm Springs" (pp. 67-72), highlights museum representation of the Aboriginal (Sahaptin-speaking Warm Springs Tribe, the Upper Chinook-speaking Wascos, and the Northern Paiute). For Clements, material culture needs to viewed in context along a continuum: "in traditional Native American cultures, art was not a separate pursuit, and the Warm Springs museum exhibition shows how beauty and utility uniquely combined in objects of everyday use to reflect a way of life and an aesthetic that respected the interrelationship between Earth and its inhabitants" (p. 67). The museum serves as an essential element in the community by showcasing tribal history, and in so doing maintains community control over how the cultures of the Warm Springs tribes are represented. Decolonization is achieved without the need to alienate non-Natives; of the seven members on the board of directors, three are non-Native.

Another chapter in the Smithsonian book, "Are changing representations of first peoples in Canadian museums and galleries challenging the curatorial perspective?" (pp. 73-88) by Michael M. Ames of the University of British Columbia. Ames asks the question: How does the collaboration between Aboriginal people and curators challenge the traditional curatorial prerogative and affect the quality of exhibitions? This question seeks to assess changes resulting from the 1992 Task Force Report on Museums and First People, a joint initiative between the Assembly of First Nations and Canadian Museums Association. Ames suggests that the task force recommendations have yet to address structural inequalities; however, the increased employment of Aboriginal people in museums, increased efforts by institutions to collaborate with Aboriginal communities, and increased opportunities for Aboriginal curators to mount exhibitions are steps towards 
better Aboriginal representation. Ames concludes his brief yet sharp essay with the assessment that "differences in how First Peoples are represented in museum exhibitions, however, may require additional changes, including the revision of internal museum cultures and professions, and the traditional curatorial prerogative" (p. 86).

In "Learn about our past to understand our future: The story of the Mille Lacs band of Ojibwe" (pp. 89-98), Joycelyn Wedll, the Director of the Mille Lacs Indian Museum, provides insight regarding the ability of museums and exhibitions to serve both specific and general audiences. Wedll speaks directly from her perspective on the Mille Lacs Indian Museum and the exhibition "Learn About Our Past to Understand Our Future." The collaboration between the Mille Lacs Band of Ojibwe and the Minnesota Historical Society (MHS) in the development of the museum is essential to the understanding of other essays in this anthology, and to the broader question of institutional representations. The care and exhibition of Ojibwe culture developed through the museum, facilitated by the donation of the Ayers private collection of artifacts to the MHS in 1960. The museum has invigorated Anishnabe culture by involving community members in the development and management of the institution within the broader context of self-governance, including Ojibwe curriculum in Mille Lacs classrooms and economic development, which supports tribal authority and traditions. Wedll concludes her essay with a discussion of ethnohistorical influences in writing Native histories, incorporating these influences in the research and display of Native histories while promoting museums as educational opportunities that reach far greater numbers than most academic discourse.

G. Malcom Lewis, editor of Cartographic Encounters: Perspectives on Native American Mapmaking and Map Use, assembled an invaluable and handsomely produced anthology, yet it lacks Aboriginal voices. The book consists of twelve chapters that cover material from the colonial period (1511-1990s). Lewis, a well-respected scholar, delivers five of the essays; the remaining chapters are contributions from seven authorities on Native North American and Mexican maps. Lewis states "when the book is reviewed, I will be particularly apprehensive concerning Part 1, and we will each look with a mixture of hope and anxiety for opinions concerning our respective contributions to Part 2" (pp. 4-5). The three chapters by Lewis that compose Part 1, "Frontier encounters in the field: 1511-1925" (pp. 932), "Encounters in government bureaus, archives, museums, and libraries, 1782-1911" (pp. 33-54), and "Hiatus leading to renewed encounter" (pp. 55-70), document three phases of Native map scholarship, or lack thereof. The first period is characterized by in situ cultural contact, where traders and missionaries influence mapping by Natives. The second period, according to Lewis, is the second-hand encounter of maps, used primarily to com- 
plete European cartographic projections into terra incognitae. It was well after 1782 that individuals began to advocate the collection of Native maps as a group. This was accelerated by developments in geography and cartography in Germany after 1870. However, many of the Native maps continued to be ignored, copied, and scattered. The three chapters in Part 1 document all known Native maps. We learn little about collectors such as James Tyrrell, Henry Youle Hind, Samuel Hearne, Meriwether Lewis and William Clark, Geological Survey of Canada, Franz Boas, and others; this book should be read along with extensive historical study. While an uneducated reader could gather much insight from the impressive research for these chapters, I feel the book is not meant for the novice. Despite its complexity, the work is an invaluable reference guide.

The locations of Native maps in libraries and archives-for example, the Hudson's Bay Company Archives (HBCA), the Thomas Fisher Rare Book Library at the University of Toronto, and the Library of Congress-demonstrate breadth of search and reflect the great effort required for material gathering. In combination, the index, chapter endnotes, and bibliographic references far outweigh any problems one might have with Lewis' interpretations, and I think it fair that one with as much experience as Lewis would be opinionated. For example, when he comments that Canadians, and to a lesser extent American scholars, were not interested in Native maps, it is made without any discussion. Similarly, Lewis makes several interesting observations about the limits of previous scholars of Native maps. However, finding documents is not a simple proposition, and perhaps the effects of colonialism or racism contributed to the lack of scholarly interest by Canadians and others. Regardless, Lewis notes that Native maps, mapmaking and use, and the documentary data have been under-used to this point. Cartographic Encounters is, in measure, an attempt to conserve and systematize pre-1925 data and to document the location of maps in a number of different collections that might otherwise be lost among other ethnographic materials.

Lewis regrets not being able to include an essay on Inuit maps, and, considering the cartographic encounters in Arctic North America, such an omission is glaring. Furthermore, a significant lack of Aboriginal voices is apparent; these maps are known as they are described and transcribed by whites over 400 years of encounters. The colonial experience has mostly been read through colonial eyes, despite research of maps by whites, maps by Natives, representations of the transcultural process, etc. This distortion is justified for the sake of knowledge production. The final period discussed in Part 1, 1911-1970, is characterized by a lack of scholarly interest in Native maps, despite the increased collection of Native Arts and souvenirs apparent in the other books reviewed. The period following 1970 marks an in- 
creased awareness of Native mapping by anthropologists and others, no longer as artifact, but now as evidence of occupation and land use.

Part 2, the bulk of the book, include essays that cover specific landscapes. Lewis, in "Recent and Current Encounters" (pp. 71-110), presents what at first glance appears to be a belabored introduction to the current scholarship of Indian maps and mapmaking but is actually a brief scholarly essay placing recent scholarship within three diverse contexts: Historical, Anthropological, and Aboriginal. Historical investigation of cartography is the greatest influence in the essays in this section, and Lewis notes that those by Belyea, Pearce, Arnold, Waselkov, and Galloway each contribute a different insight relevant not only to geography but also to the historiography of cartography. In the second category, Lewis notes "anthropologists have shown less interest in maps than historians and archaeologists, and their work has sometimes been controversial" (p. 83). The essays by Nabokov and Boone are classified as anthropological. The Aboriginal context has no specific essay assigned to it; however, identity politics aside, the epistemological or cosmological position in the book is valuable. Lewis provides insight about "mapmaking as a component of commercial art; and bioregional mapping, most of it in the course of mounting legal challenges against government control over their traditional territories" (p. 94).

The essays by Elizabeth Hill Boone, "Maps of territory, history, and community in Aztec Mexico" (pp. 111-134), and Peter Nabokov, "Orientations from their side: Dimensions of Native American cartographic discourse" (pp. 111-134), place Native maps and mapmaking within a larger social context. Boone considers Aztec maps to be writing systems that evolved out of the interaction with Spaniards. Aztec maps became records of movement from the past, as the people organized themselves in relations to the Spanish. Nabokov discusses Native maps as cartographic discourse, where space serves as a mode for cross-cultural expression, "a rhetorical device for staking out social or diplomatic positions, or a visualization technique often used in conjunction with oratory or storytelling for the charting of proper behaviors or spiritual development" (p. 241). For Nabokov, the act of mapping and the map itself is evidence of the attempt to establish cultural and political authority. The essay by Barbra Belyea, "Inland journeys, Native maps" (pp. 135-156), challenges the idea that Native geographic knowledge was translated to fit European scientific mapping conventions. Belyea argues that maps are conventional; conventions determine perception, yet that perception is culturally specific. According to Belyea, "accounts of maps are products of reformulating and reconfiguring what they [Europeans] could of a foreign [Native] convention in terms of their own" (p. 135). There is great value in researching Native maps as "graphic forms which represent a worldview that which is utterly different from the produced by European 
scientific cartography" (p. 140). This position makes us cautious of documentary records that claim to represent Native worldviews; as Belyea notes, "all we have left are the graphic transcripts, without explanations, memories, or associations" (p. 148).

In "Native mapping in southern New England Indian deeds" (pp. 135156), Margaret Wickens Pearce demonstrates how colonial maps sought to erase Native maps. Pearce urges that the search for Native maps requires looking for more than pictorial representations-for example, examining the negotiation and registration of Indian deeds. Pearce calls for a flexible definition of mapping, "maps are representations that facilitate a spatial understanding, and mapping is the process of creating and interpreting these representations" (p. 151). In reinscribing the landscape, colonials sought to replace Native toponyms, and Pearce notes how these place names function as mnemonic devices. Morris S. Arnold, author of "Eighteenth-century Arkansas illustrated: A map within an Indian painting" (pp. 187-204), supports Pearce's suggestion to search for Native maps elsewhere. By examining a specific buffalo hide painting held at the Musee de 1'Homme in Paris, Arnold argues for a Quapaws provenance, establishing the painting's context both artistically and cartographically. In a somewhat speculative scholarly debate, Arnold challenges historical interpretations; he asserts that while the motifs and images of the robe painting contain spatial elements of an event, that event is also indicative of the design and execution by a Quapaw Indian and a French man collaboratively-perhaps the artists was a Metis. In his essay, "Indian maps of the colonial southeast: Archaeological implications and prospects" (pp. 205-222), Gregory A. Waselkov notes that archaeologists have mostly ignored Native maps, which represent long-vanished social landscapes. Waselkov finds the nature of cartography and archaeology to be complementary and that specific sites and communication routes can be traced through the interchange. Patricia Galloway, in "Debriefing explorers Amerindian information in the Delisles' mapping of the southeast" (pp. 223-240), argues that mapping was a result of the conflicts and competing claims for land. Borrowing the "event transcription" concept from Elizabeth Boone and the concept of the "sociograms" as noted from Gregory Waselkov, Galloway argues that maps diagram social networks and that the graphic representations denote the connections between individuals and groups. Galloway's essay is taken up with an investigation of the Delisle cartographic house. Lewis concludes the anthology by indicating the possible paths for future scholarship, including the use of Native maps in legal contexts, or to study language, cognitive sciences, social science, and the arts.

Ruth Philips, Professor and Director of the Museum of Anthropology at the University of British Columbia, presents research on commodity arts of 
Natives in northeastern North America during the early contact period, from 1700 to 1900 . The book is well suited for a general audience, although it is written for those seeking to identify and document objects in public and private collections. A significant contributing concept, among many in the book, is a dismissal of the authenticity paradigm that is continually used in art history to marginalize some commoditized objects over others. Trading Identities takes the category "souvenir" as an important and worthy topic of study for historians. These artifacts provide an important enthographic window into the lives of Native creators and non-Native collectors, many of whom share the common trait that they were women of the lower-middle classes; this is, according to Philips, an otherwise neglected segment of society. Philips studies these representations using a triangulation of archival and museum research with the preexisting literature base (literature from both the mainstream and critiques) and fieldwork. Employing a case study approach by conducting field research at three First Nations communities (Kahnewake-Mohawk, Eskasoni-Mi'kmaq, Michigan/Manitoulin Island-Odawa/Ojibwe), Philips submits a regional Aboriginality, a utility of her research approach and its shortcoming. The benefit of the case study approach is the reclaiming of souvenirs from the margins as transcultural aesthetic production. The research approach proposes oral history as the filter through which to read documentary evidence produced by non-Natives. This approach would be helpful in addressing problems inherent in the reading of documents to the exclusion of communities, which often produces a poor representation or misrepresentation of Aboriginals (Krech III 1999; Flanagan 2000). One shortcoming of the field research approach is the question of how representative they are to the region and the acknowledgment of changes to legitimate topics and methods of study in art history. This book is indeed a step towards a better understanding of Native art through souvenir production and consumption. There is much more to research particularly the Aboriginal artisans' perspectives on the production, trade, consumption, and representation of their wares.

Five luxuriously rich chapters challenge what Philips considers a privileged perspective: male art categories that have reduced women's arts to crafts. Philips rewrites a small-scale history of Native art to include commoditized products as essential. In doing this, she interrogates how the art was collected and displayed. Anthropologists and others will be interested to read her chapters deconstructing the "natural man" trope. A central and powerful critique informs Philips analysis; issues of gender surface continually while she is establishing provenance for pieces and contextualizing the lives of women as artists and visitors in the tourist trade. In concluding her books, Philips leaves the reader with a deep essay on the critique of the touristic in contemporary art practices. Philips showcases 
both souvenir works and her critique of art history, through a richly informed book, including insights gathered from contemporary native artists, such as Tom Hill, Jolene Richard, Daphne Odjig, Gerald McMaster, Rebecca Baird, and Norval Morriseau.

There are limits to most modes of thinking, and it would be foolish to endorse any one approach (Harkin 1988, Maclear 1993, Chalmers 1995, Errante 1999). The ex situ fails to consider how current communities maintain traditions in the face of many changes they have experienced as readily as it gives insight to what those inside can not see. While the in situ is not all that concerned with larger trends or what has occurred beyond the boundaries of the local, such a perspective is a legitimate position from which to view the world. There are bridging ideas that melt much of the polarity of the in/ex situ binary. The cultural core concept suggests that Aboriginal communities have always adapted to new conditions. Likewise, if Aboriginal communities are viewed as Diasporas, they can be researched for both enrichment and displacement. The questions of power and authenticity, voice, identity, legitimacy, appropriation, and misrepresentation, are collectively faced by Native and non-Native under the colonizing pressure of late twentieth century global economic forces. As I read these books, I struggled to reexamine my categories of Aboriginal, Canadian, and American. Each obvious and unconscious twist of labels and their binary oppositions that result from defining and naming - regardless of some utilitarian purposes, political action, family obligations, etc.-left me cold and unsure. Perhaps it is the uncertainty produced by questioning entrenched representations that is the most interesting effect of each of these books. When read collectively, their impact is like an impressive hammer blow to the imaginary Indian constructed by the colonial other. The unsettling process of sorting through the shattered pieces that remain is necessary. We can be sure that Aboriginal peoples in North America face a number of issues regarding representation. Too often we read about Europeans entering the continent, learning about the lands, waterways, and other peoples from well-established and diverse Aboriginal informants, most of whom remain nameless. North America was not a blank slate. Spaces were occupied and the knowledge of the land reflected the diversity of the people who lived on it. The images they produced of themselves are rich and continue into the future.

These books attempt to address the misrepresentations, whereas in the past such issues were ignored or criticism was silenced completely. The many voices beyond the winners of wars and industrialists (Lepore 1999) are now replacing the single "expert" voice (collector or curator). My fear is that there may still be a tendency in scholarship to defer to books when there is much more at stake than citing the authoritative text (this discussion is beyond the scope of this essay). We should celebrate the instances of 
collaborative work, the growing number of Aboriginal and other professionals involved in reforming representations. It is clear, however, that there remains a considerable gap between what we have and more perfect representation of Aboriginal people in cultural institutions. Yet, in the books under review there is an overwhelming erasure resulting from reading too many colonial documents and records, exacerbated by the isolation from Aboriginal ancestors and communities (but obviously in close contact with representations of them or their ancestors). The distance between researchers and the researched is deep. Another significant issue these books raised for me was to understand modes of acculturation. The collective realization of change, including adding new people to indigenous personal knowledge, is often discussed as binary arguments of enrichment (Fisher 1977) and devastation (Frideres 1988). The "contact zone" is possibly the most salient site for problematizing these two divergent ideas. Even so, artifacts and other representations inform us of how the contact zone continues to shift across time and space. Like colonization, contact is continually changing; to suggest we are postcolonial negates much of what contact means in the first place. In a new form of resistance and accommodation, decolonization is, for many Aboriginal communities, maintenance of traditions in contemporary times. As a body of work, these books provide no tangible solution to the question of who has the legitimate right to study Aboriginal representations but they do speak of the proliferation of scholarship.

The ways institutions think will ultimately color the representations they produce (Douglas 1986). Cultural industries will continue to colonize Aboriginal peoples as long as the public consumes representations. Postsecondary institutions also play a significant role in protecting and encouraging the robbing of graves and stealing of bones in the name of science (Churchill 1995). How Aboriginal people are represented and how these representations are then consumed by the public are important areas for us to consider (Torgovnick 1990; Francis 1992; Krech III 1999). To improve our knowledge we must continue to examine the ways institutions think; the epistemology of institutions will tell us about the very essence of how we know what we know. How institutions think, which is revealed in their practices and processes, often demonstrates power imbalances; when it comes to representations of class, gender, ethnicity, or age, the vast majority of institutions are projecting representations of themselves onto others (Gleach 1996). If we can move beyond the limited studies of hegemonic discourse and find space to insert multiple representations of the world from a plethora of others, then the "othering" that takes place can have the potential to be unpacked, demystified, and decolonized. The search for Aboriginal representations inside institutions begins the very real possibilities of improving the ways institutions think. 
While the issues I have been discussing give cause for celebration, there continue to be a growing number of misrepresentations of Aboriginal individuals, communities, and pan-Indianism that engender pessimism. At worse, these representations, images, and tropes are becoming generalized and perpetuated parodies of Aboriginal people, functioning as triggers for racism. Much of the interest in continued institutional representations of Aboriginal people flow out of the insecurity of mainstream societies, which at its foundation is rooted in colonization. The fact is that in most cases representations are inaccurate; a sense of wonder often inspires indifference (Gleach 1996). The often emotional ties that bind newcomer and indigenous on a shared path of learning is often overlooked (Brown 1980, Van Kirk 1980). It should not strike us as unusual that Aboriginal representations reflect a curious outsider perspective that mirrors an entrenched way of knowing derived from organizations that are not derived from Aboriginal cultural traditions. We are all influenced by modernity (postmodernism) and some have argued, postcolonialism. There are in fact a growing number of Aboriginal representations in Aboriginal and non-Aboriginal communities, including institutions and books, that have taken a hybrid approach to both specific and general Aboriginal cultures, representing them as dynamic, living, and transcultural experiences.

\section{REFERENCES}

Brown, J. S. H. (1980). Strangers in blood: Fur trade company families in Indian country. Vancouver: University of British Columbia Press.

Canadian News Wire. (2001). Sheila Copps announces \$1.23 million for Aboriginal Museum development at Parks Canada round table on Aboriginal tourism. Brantford, May 11.

Chalmers, F. G. (1995). European ways of talking about the art of the Northwest Coast First Nations. Canadian Journal of Native Studies, 15 (1), 113-127.

Churchill, W. (1995). Since predator came: Notes from the struggle for American Indian liberation. Littleton: Aigis Publications.

Douglas, M. (1986). How institutions think. Syracuse: Syracuse University Press.

Errante, A. (1999). But sometime you're not part of the story: Oral histories and ways of researching and telling. Educational Researcher, 29 (2),16-27.

Fisher, R. (1977). Contact and conflict: Indian-European relations in British Columbia, 1774 1890. Vancouver: University of British Columbia Press.

Flanagan, T. (2000). First nations? Second thoughts. Montreal: McGill-Queen's University Press.

Francis, D. (1992). The imaginary Indian: The image of the Indian in Canadian culture. Vancouver: Arsenal Pulp Press.

Frideres, J. (1988). Native peoples in Canada: Contemporary conflicts. Scarborough: PrenticeHall Canada.

Gleach, F. (1996). Controlled speculation: Interpreting the saga of Pocahontas and Captain John Smith. In Jennifer S. H. Brown and Elizabeth Vibert (Eds.), Reading beyond words: Contexts for native history (pp. 21-42). Peterborough: Broadview Press. 
Harkin, M. (1988). History, narrative and temporality: Examples from the Northwest coast. Ethnobistory, 35 (2), 99-130.

Krech III, S. (1999). The ecological Indian. Myth and history. New York: Norton.

Latour, B. (1986). Visualization and cognition: Thinking with eyes and hands. Knowledge and Society: Studies in the Sociology of Culture Past and Present, 6, 1-40.

Lepore, J. (1999). The name of war: King Philip's war and the origins of American identity. New York: Knopf.

Maclear, K. (1993). The art of a colonial education. Harbour, 2 (2), 38-41.

Said, E. (1993). Culture and imperialism. New York: Vintage Books.

Torgovnick, M. (1990). Gone primitive. Savage intellects, modern lives. Chicago: University of Chicago Press.

Van Kirk, S. (1980). "Many tender ties": Women in fur-trade society in Western Canada, 1670-1870. Winnipeg: Watson \& Dwyer Publishers. 
